\title{
The Ottawa Field-Naturalists' Club Awards for 2012, Presented April 2013
}

\author{
Eleanor Zurbrigg, Irwin Brodo, Julia Cipriani, Christine Hanrahan and Ann MacKenzie
}

On April $20^{\text {th }}, 2013$ members and friends of the Ottawa Field-Naturalists' Club gathered at the Club's Annual Soirée at St. Basil's Church in Ottawa. Awards were given to members and non-members who distinguished themselves by accomplishments in the field of natural history and conservation, or by extraordinary activity within the Club. In particular, protection of natural features and landscapes, butterflies and their con-

\section{Honorary Member: Dr. J. Bruce Falls}

This award is presented in recognition of outstanding contributions by a member or non-member to Canadian natural history or to the successful operation of the Club. Usually people awarded an honorary membership have made extensive contributions over many years.

The ideal Honorary Membership reflects the three elements of the OFNC's mandate, the investigation of natural history, documentation of original research, and the appreciation and protection of important Canadian natural landscapes. The achievements of Dr. Bruce Falls fully embody all of these important characteristics.

Bruce Falls is a lifelong southern Ontario naturalist and eminent zoologist who has conducted and directed ground-breaking research into a variety of fields (notably breeding bird biology) during a lengthy tenure at the University of Toronto. This achievement is reflected in the establishment of the J. Bruce Falls Scholarship in Ecology and Evolutionary Biology. The web page information on that scholarship summarizes his academic achievements:

"... .besides undergraduate teaching he supervised the research of 36 graduate students and five post-doctoral fellows. He was an author of over 100 scientific publications. Much of his research took place at the Wildlife Research Station in Algonquin Park, and some at the Delta Field Station of the University of Manitoba. Helped by his wife Ann, also a biology graduate of $U$ of $T$, he conducted a 36-year study of small mammal populations in the Park. Fluctuations in abundance were strongly influenced by weather and tree seed crops and in turn affected the numbers of predators.

Dr Falls' main interest was in bird research. He was a pioneer in the study of bird song and its relation to territorial behaviour, basing his findings on field experiments. ... Dr. Falls is a member or fellow of several scientific societies and a past-president of the servation, management of the Club's scientific journal, Fletcher Wildlife Garden efforts, turtle research and conservation, sand dune restoration, and nocturnal micromoths are all in evidence among this year's winners. Short versions of the following seven citations for those who received an award were read to the members and guests assembled for the event.

\section{Society of Canadian Ornithologists". (http:// www.eeb.utoronto.ca/about-us/support_us /ugradschol/usfalls.htm)}

Always a keen naturalist and especially active as a birder in the Toronto area, Bruce Falls became involved in conservation organizations at an early age. He was heavily involved in the Federation of Ontario Naturalists (now Ontario Nature), initiating the FON's nature reserve program as a Director and serving as President in 1962-1963.

He applied the experience gained in development of the FON's reserve system to the national scene, being instrumental in the establishment of the Nature Conservancy of Canada, which had secured the protection of over 1 million ha of natural lands in Canada to the end of 2012, a year which also marked its $50^{\text {th }}$ anniversary. (http://www.natureconservancy.ca/en/what -you-can-do/learn-more/the-ark/champions-of-con servation/j-bruce-falls.html).

A summary of his extraordinary breadth of conservation activities is included in the biographical material in his file at the University of Toronto Archives:

"...membership in the Federation of Ontario Naturalists (director, 1946-1974; president 1962-1964; and chairman of Nature Reserves Committee, 1965); scientific advisor to the Ontario Waterfowl Research Foundation, 1960-1968; trustee (from 1962) and chairman (1971-1974) of the Nature Conservancy of Canada; member of the Conservation Council of Ontario (from 1962), Canadian committee of the International Biological Programme (conservation sub-committee member and co-chair of the Ontario panel, 1968-1974), member from 1969 at various dates of the advisory committees of the Ontario Ministry of Natural Resources on nature reserves, Minesing Swamp and the Backus Tract; honorary director from 1970 and director in 1989 of the Long Point Observatory, director from 1975 of the Owl Rehabilitation 
Research Foundation, member from 1981 of the Canadian Council on Ecological Areas, member of the management committee (1981-1987) and chair (1983-1987) of the Atlas of the Breeding Birds of Ontario, and member of the Ontario Rare Breeding Program (chair of management committee, 1989)". (http://utarms.library.utoronto.ca/res earchers/james-bruce-falls)

\section{Honorary Member: Peter W. Hall}

This award is presented in recognition of outstanding contributions by a member or non-member to Canadian natural history or to the successful operation of the Club. Usually people awarded an honorary membership have made extensive contributions over many years.

Peter Hall is an outstanding naturalist, whose interests range far and wide, encompassing in particular, birds and butterflies. It is the study of the latter which has occupied a good deal of his time, and he is certainly best known for his expert knowledge on butterflies and their conservation, about which he has spoken and written widely. Peter is very generous with his time, always willing to help with questions about butterflies, and to share his knowledge with others.

Peter was employed for many years by Agriculture and Agri-Food Canada (AAFC), first as a communications writer, editor, and later as Acting Director General, then as a senior executive in the areas of communications, publishing, strategic planning, and administration. However, conservation has always been central to Peter's life, and in 1999 he began a decade of working exclusively in this area. From 1999 to 2000, he was the National Director of the Canadian Environmental Network in Ottawa, the umbrella group for 600 Canadian environmental NGOs. Between 2000 and 2004, Peter was Executive Director of the Federal Biodiversity Information Partnership, coordinating biodiversity information management in Canada. From 2004 to 2006, he was Director, Biodiversity Information Services and a member of the Management Committee at the UNEP-World Conservation Monitoring Centre, in Cambridge, UK, where he represented the UN at international fora on biodiversity and biological research issues. Returning to Canada, he spent several years as Senior Advisor, Biodiversity, at AAFC, focusing on long-term maintenance of the Canadian National Collection (CANACOL) of insects and plants, before retiring in 2008. A published report, Canadian Taxonomy: Exploring Biodiversity, Creating Opportunity, grew out of his role as Member of the Expert Panel on the State and Trends of Biodiversity Sciences of the Council of Canadian Academies.

Peter is co-author (with Ross Layberry and Don Lafontaine) of the first truly comprehensive guide to Canadian butterflies, The Butterflies of Canada (1998), a seminal work that helped generate fresh interest in
The Club is proud to offer Honorary Membership to Bruce Falls to recognize his immense contribution to the investigation, documentation and protection of natural features and landscapes in Ontario and throughout Canada.

(Prepared by Eleanor Zurbrigg, based on material from Dan Brunton and Francis Cook)

Canadian butterflies by providing a means of identification for all Canadian species. Long before this publication, Peter was author, or co-author, of many other articles on butterflies. Of particular interest to an Ottawa audience is the article in the 1982 issue of Trail \& Landscape on Butterflies of the Ottawa District, written with the same two co-authors noted above, and the 1996 Checklist of Butterflies of the Ottawa District. More recently, Peter authored a very essential report, Sentinels on the Wing: The Status and Conservation of Butterflies in Canada on behalf of NatureServe Canada. At present, he is working on a Royal Ontario Museum field guide to butterflies of Ontario, a publication eagerly awaited by many.

Peter continues his research on butterflies and their conservation, as an Honorary Research Associate at CANACOL, Agriculture and Agri-Food Canada, where he curates the Lepidoptera Collection. Furthermore, he is frequently called upon to give public lectures about various aspects of butterflies; in 2011, he was invited by the Toronto Entomologists' Association to give the inaugural lecture for the Quimby F. Hess annual lecture series. Peter spoke about butterfly conservation, population status, and how our butterflies can be protected.

In addition to Peter's many accomplishments in the world of Lepidoptera, he has also been intimately involved with The Ottawa Field-Naturalists' Club for over 30 years. He was a long-serving Associate Editor of Trail \& Landscape (1981-1993). He has been a member of OFNC Council as well as various committees. He has led many club walks over the years, most recently summer excursions to look for butterflies in Larose Forest.

As well as the butterfly-focussed articles above, Peter has written on topics as varied as otters, mosquitoes, and the Central Experimental Farm, for Trail \& Landscape. Peter has also published widely in journals as diverse as Biodiversity: Journal of Life on Earth and the Canadian Journal of Zoology.

One of the most enduring projects of the OFNC, the Fletcher Wildlife Garden, is the brainchild of Peter, who along with his wife, Judy, conceived the idea of a wildlife garden to celebrate Wildlife '87. As noted in a press release from the Canadian Wildlife Service at the time, "The focus of Wildlife ' 87 is on conservation of wildlife and its habitat." Peter took that theme 
and flew with it, and by the summer of 1990, the Fletcher Wildlife Garden held its grand dedication ceremony, to which over 1,400 people came. The thriving garden is now a well-known entity amongst many in the city, and beyond. It is a fitting legacy for someone who has spent his life watching and protecting butterflies, for the garden has become a haven for a diversity of butterflies, as well as a myriad of other wildlife.

\section{Member of the Year: Jay Fitzsimmons}

The OFNC's Member of the Year award recognizes the member judged to have contributed the most to the club in the previous year.

This year we are recognizing Jay Fitzsimmons for his work managing the electronic publishing of the Canadian Field-Naturalist (CFN) and also for his enthusiastic and far-reaching promotion of the journal.

Jay joined the Publications Committee in 2009 and soon started championing an electronic version of the CFN. He was not only vocal about it; he was actually willing to do all the hard work to make it happen. In the fall of 2011 the first electronic issue of the CFN was published, Volume 125(1), and the CFN moved into a new era with Jay as the volunteer Journal Manager.

Being the journal manager for the $\mathrm{CFN}$ is a big job. With one hand he tracks renewals and money coming in for subscriptions and author charges. With his other hand he looks after all the technical issues of publishing online. At one point Jay realized that people using Internet Explorer were having difficulty with parts of the download. Another time he realized we needed to change servers, so he put together a proposal for Council to make it happened quickly. It is at least in part a testament to his beyond-the-call-of-duty efforts that there has been no decline in the number of CFN subscriptions during its transition to a predominantly electronic form.

However, Jay was not content to stay in the background keeping the machinery running. He has become one of the best promoters of the journal. At the 2012
Peter is also active with the Monarch Waystation at the garden, providing leadership and guidance for the project.

For all of these reasons, it is a pleasure and privilege to bestow upon Peter W. Hall, an Honorary Membership in the Ottawa Field-Naturalists' Club.

(Written by Christine Hanrahan)

Evolutionary Conference in Ottawa he teamed up with the Editor-in-Chief, Carolyn Callaghan, to make their presence felt. Banners were created and promotional postcards were handed out with a $\mathrm{QR}$ code linking to the CFN website. He created a Twitter account to tweet at the conference to get more followers. Post-it notes invited authors to publish their research with the CFN. Similarly, in the fall Jay represented the CFN at an Ontario entomological conference and equally promoted the journal.

Jay started a blog that linked to the CFN website to communicate with those interested in the evolution of the CFN. It is chatty, funny and very interesting. In it he gets excited when a new issue is being published and gives highlights of its contents. He explains any glitches in publishing. He helps draw scientists back to it by providing lists of related conferences and other blogs. The tone is up-beat and lively. In addition he continues the twitter account and monitors the impact of it on hits to the CFN webpage. No one could call the CFN stodgy.

In his "spare" time in 2012, Jay completed his PhD in the field of insect ecology, and became a Science Advisor for the Canadian Wildlife Service. On the home front he is married with two pre-school children to keep him busy.

Jay is one part technical manager, one part firefighter and several parts cheerleader. For all these reasons we want to recognize his efforts in 2012 to help the club's journal realize its full potential.

(Written by Ann MacKenzie)

\section{George McGee Service Award: Constance Clark}

The George McGee Service Award is given in recognition of a member who has contributed significantly to the smooth running of the Club over several years.

Connie Clark has been a member of the Ottawa Field-Naturalists' Club since 1988. She has been a volunteer at the Fletcher Wildlife Garden (FWG) since its inception. She has contributed articles to Trail \& Landscape, has been a leader and co-leader of many outings and was a mainstay as the food co-ordinator for the annual Soirée for 6 years.

Her volunteering at Fletcher began in 1990. She was one of the first people to help plant trees in the New Woods area when it was still a grassy lawn in the very early days of FWG. However, in those pre-retirement days, Connie was pretty busy with other activities, and it wasn't until 2003 that she came back to the FWG.

While Connie's interest is in the forests and woods, Marilyn Ward encouraged her to give the Back Yard Garden (BYG) work a try. She found it interesting, and it was the Woodland Walk section that convinced her to remain. With the treed ravine on one side, tall shrubs on the other and a remarkable diversity of native woodland plants flourishing along the short trail, she was hooked. She took over responsibility for the Woodland Walk the next year. She began working on other parts of the BYG, doing a little bit of everything. In her third 
year she focused on the Heritage Bed and the Rockery. For several years she grew hundreds of plants from seed in her home in preparation for the annual FWG Plant Sale. She has been a member of the Friday morning group for 10 years, bringing her commitment, determination and quiet support to the BYG, contributing her time and energy to whatever needs doing. In addition she has staffed the OFNC booth created by Education and Publicity on several occasions.

Connie is a terrific all around naturalist. Her curiosity about the natural world led her to immerse herself in places like Algonquin Park for extended periods learning about, researching and studying everything that caught her eye. From 2005 to 2010 Connie was a member of the Excursions and Lectures Committee. During this period she organized and co-ordinated dozens of outings. She led or co-led 16 outings herself, introducing participants to many of the rich and accessible places to explore in the Ottawa area. While she focussed on flowers, ferns and fungi, Connie's broad knowledge of and interest in the natural world made her an extraordinary leader. She prepared thoroughly for every out-

\section{Conservation Award - Member: David Seburn}

The Conservation Award for a member is given in recognition of an outstanding contribution by a member in the cause of natural history conservation in the Ottawa Valley, with particular emphasis on activities within the Ottawa District.

David Seburn is an independent researcher specializing in the conservation of amphibians and reptiles, particularly turtles. This award recognizes David's significant efforts for over a decade in turtle research and conservation in the Ottawa area.

Work on turtles is crucial, as seven of Ontario's eight turtle species are on the Species at Risk in Ontario List. Threats include habitat loss and fragmentation, road mortality, persecution, illegal collection for the pet trade and pollution.

In 2011-12, David did yeoman's service as a diligent local advocate for the campaign to get the Ontario government to protect Snapping Turtles from hunting. Although the campaign was not successful, local efforts such as David's help to highlight the issue and raise awareness for OFNC members by providing information and advocating for change. David has also been involved in the OFNC's advocacy efforts to influence the City of Ottawa to promote conservation of Blanding's Turtles threatened by the Terry Fox Drive/South March development.

David's research and monitoring of turtles in the Ottawa region has produced significant results. For example, surveys he conducted of Spotted Turtles - an endangered species - at a site in eastern Ontario resulted in the site being acquired by the Nature Conservancy of Canada. David has also been conducting population monitoring of Spotted Turtles at another site in the ing, scouted out the conditions, made extensive notes and prepared presentations to introduce participants to the area of focus. She kept detailed written and photographic records of sightings on her outings and shared her field notes with participants, providing valuable knowledge regarding timing and location of her findings. Her articles about Monaghan Forest and Poison Ivy were published in Trail \& Landscape, along with her poem, There Have Been Days.

In addition to her key role as co-ordinator of the food purchasing and preparation for the Soirée for several years, one year Connie prepared a nature quiz for the entertainment of attendees. She also wrote and performed nature themed songs.

The Club has benefited greatly from Connie's general knowledge, experience and botanical know-how. It is for her quiet, behind the scenes generosity of time and energy that we wish to honour Connie with the George McGee Service Award for 2012.

(Written by Julia Cipriani with input from Christine Hanrahan)

Ottawa area since 1999, building on a previous researcher's 1980's work, and resulting in an impressive 30 year data set for this project. David's work has included tracking individual turtles using radio transmitters, which has demonstrated that some turtle populations may be relatively immune to the threat of traffic mortality if they remain within large wetlands. This result provides the scientific basis for putting a conservation priority on the identification and protection of such sites.

David also undertook a study to identify Blanding's Turtle habitat use during hibernation at a site in eastern Ontario, and the results of this study are published in The Canadian Field-Naturalist (2010). He also wrote a conservation assessment for Blanding's Turtle in 2002. Blanding's Turtles have been a hot topic in the ongoing fight against developing the South March Highlands in Kanata.

David tirelessly promotes turtle conservation through presentations to groups such as naturalists, conservation professionals and even water garden enthusiasts, covering topics such as Ontario's turtles, population trends of turtle species in the Ottawa area and how to make your water garden turtle-friendly. David has also provided training on turtles to conservation partners, written general articles for the public ("help a turtle cross the road"), and participated on the Ontario MultiSpecies Turtles at Risk Recovery Team when it was active. David is currently the Ottawa area regional coordinator for the Ontario Reptile and Amphibian Atlas.

The Club has truly benefitted from David's membership. He is not only active in the Conservation Committee but he and his family are active in the Macoun 
Field Club for young naturalists, helping to pass his conservation knowledge and ethic to the next generation.

For his many contributions to turtle conservation in the Ottawa area and more broadly, the OFNC is pleased to present David Seburn with the Conservation Award for a Member for 2012.

(Written by Eleanor Zurbrigg)

\section{Conservation Award - Non-Member: Biodiversity Conservancy International and National Capital Commission}

The Conservation Award for a non-member is given in recognition of an outstanding contribution by a nonmember in the cause of natural history conservation in the Ottawa Valley, with particular emphasis on activities within the Ottawa District.

This year the award goes to Biodiversity Conservancy International (BCI) for the "National Capital Greenbelt Sand Dune Conservation Project" at the Pinhey Sand Dune and its partner the National Capital Commission.

The initiative began with the realization that the Pinhey dune, located off Slack Road, between Woodroffe Avenue and Merivale Road, was going to disappear. This is a unique habitat of dry, open, inland sand deposits not directly associated with rivers or lakes. The specialized flora and fauna found in these areas include provincially and regionally rare species.

The dunes were formed on the edges of the early postglacial Champlain Sea approximately 8,000 years ago. Over the past 60 to 70 years in eastern Ontario, the dunes have declined to only one per cent of their natural coverage. Trees, invasive shrubs, urban sprawl and the cessation of fire were all contributing to the loss of this unique habitat.

Of particular interest and concern is the ghost tiger beetle - a 12-millimetre long insect the same colour as the fine-grained sand and whose only home in Ottawa is the dunes on Slack Road. The beetles are not the only insects in this extreme environment. There are also Ant Lions which dig pits to trap ants.

In 2011, Biodiversity Conservancy International, a local scientific non-governmental organization, took the lead. Pete Dang and Henri Goulet went to the Trillium foundation and got $\$ 10,000$ in June 2011 to restore and expand the dunes over the next two years. Next they approached Eva Katic at the National Capital Commission who quickly became an enthusiastic supporter.
The organizing committee consisted of Pete Dang, Project Director, Stephen Aitken, Project Coordinator, Henri Goulet, Biodiversity Assessment, Joanne Hakkaku, Community Engagement and Volunteer Coordinator, Nina Edson, Volunteer Recruitment, Andrew Mott, Field Operation, TD Trinh, Logistics and Team Coordinator and John Davidson, Communications.

By the late summer of 2012 considerable work had been done along with a major education effort. Working with many community volunteers they were successful in opening up an area of the dune by removing small trees and buckthorn shrubs by hand, using shovels and spades. The group worked with aerial images of the area over the last 75 years to track some of the damage, then removed plants, weeds and trees to reclaim some of the habitat.

As the restoration process continued in the fall of 2012, the NCC provided heavy equipment to cut trees and dig out stumps to remove encroaching vegetation. When they were finished an area of over four times the original sand area was opened.

One of the mandates of the initial funding was to establish a mechanism to conserve the restoration accomplished by the project. In October, 2012, BCI created Stewards of Sand Dunes (SOS-Dunes) as the permanent steward of the sand dune system in Ottawa.

Now that the dunes have been restored to some of their former glory, the BCI - SOS-Dunes acting as stewards, and the National Capital Commission as the property owners, will work together as caretakers to protect the habitat and to educate the public with signage about the ecology.

This is a wonderful example of community-based conservation which brought a diverse group of people together.

\section{(Prepared by Ann MacKenzie, based on material from Paul Catling)}

\section{Anne Hanes Natural History Award: Diane Lepage}

The Anne Hanes Natural History Award recognizes outstanding contributions of an amateur naturalist to our understanding and knowledge of the natural history of the National Capital Region.

This year, the worthy recipient is Diane Lepage.

Moths are considered by some to be the "poor sisters" of the more widely appreciated butterflies. Not so for Diane Lepage, who has made the study of moths her special passion. She is not only interested in the spec- tacular, brightly coloured types like the huge silk moths that are familiar to most naturalists, but also the much smaller, mostly nocturnal species aptly named "micromoths," of which there are hundreds. It requires special techniques to discover these creatures, involving ultraviolet lights, long nights in the woods or along roadsides, and ways of documenting what you find. For many entomologists, this means a killing jar and long hours spent spreading wings and writing labels. 
In Diane's case, the documentation is the non-lethal method of photography (in almost all cases). Several years ago, she gave a fully illustrated talk on moths to the Ottawa Entomology Club.

In the March 2013 issue of Trail \& Landscape, Diane summarized five years of moth study at the Larose Forest, an ecological reserve 45 minutes east of Ottawa. In a lively and well-written article illustrated with her beautiful black-and-white photographs, she explains the importance of moths, something about their natural habitats and life histories, explains their taxonomy, and gives hints for observing them. This is followed by an astounding list of the 351 species she discovered, complete with scientific and vernacular names. This would make the Larose Forest one of the most intensely studied areas of eastern Canada for the moth fauna. Diane notes that every time she returns to the Forest, she encounters new species for her list, and so it is clear that many more species remain to be discovered.

Diane has not only looked at the moths of Larose Forest. Her observations have been made throughout the Ottawa Region and sometimes beyond. She has led well-attended OFNC evening excursions to share the experience of seeing night-flying insects with other Club members. She is a frequent participant in BioBlitzes in the region, also adding to our knowledge of the moth fauna. Professional entomologists, such as Dr. Don Lafontaine at Agriculture Canada's insect collection, regard Diane as great source of information, and she is acknowledged by them as an expert on the moths of eastern Ontario and western Quebec. Her donations of interesting and significant moth specimens to the National Collection are highly valued and appreciated.

Not surprisingly, Diane is also interested in butterflies, and she is one of the leaders of the annual Butterfly Count. Her tireless work at the Fletcher Wildlife Garden's Butterfly Garden resulted in her being given the Member of the Year Award for 2008.

Diane's work is an excellent example of what a dedicated and knowledgeable amateur can achieve in making lasting scientific contributions. This is precisely the kind of individual that merits the Anne Hanes Natural History Award, and it is with great pleasure that we award it to Diane Lepage this year.

(Written by Irwin Brodo) 